\title{
NAÇÃO E HISTÓRIA: JULES MICHELET E O PARADIGMA NACIONAL NA HISTORIOGRAFIA DO SÉCULO XIX
}

\author{
Afonso Carlos Marques dos Santos \\ Titular em Teoria e Metodologia da História-UFRJ
}

\section{Resumo}

Este artigo trata da idéia nacional, da nação como um artefato cultural dotado de força simbólica, plasmada na experiência histórica do século XIX. A obra de Michelet é aqui examinada como expressão desse fenômeno.

\section{Abstract}

This article deals with the Idea of 'national', of 'nation' as cultural artifact, charged with a symbolism typical of a specific historical experience of the XIX $^{\text {th }}$ century. Michelet's work is examined here as expression of this situation.

\section{Pallavras-Chave}

Nação - Identidade Nacional - historiadores (séculos XIX e XX), Michelet - França

\section{Keywords}

Nation - National Identity - Historians (XIX e XX centuries), Michelet - France 


\section{I - Identificação do Fantasma}

Roland Barthes, na sua "aula inaugural", proferida no Colégio de França em 7 de janeiro de 1977, importa da psicanálise o termo fantasme para expressar a questão ou inquietação que os professores deveriam apresentar no momento exato de decidir sobre a direção do seu trabalho em cada período letivo, isto é, "no momento de decidir sobre o sentido de sua viagem". Barthes considera que é a um fantasma ${ }^{2}$, “dito ou não dito, que o professor deve voltar anualmente". Desta forma o professor se desviaria do lugar onde sempre é esperado, "que é o lugar do Pai, sempre morto, como se sabe; pois só o filho tem fantasmas, só o filho está vivo". A ironia de combatente da linguagem leva Barthes a perguntar: "se considerarmos um instante a mais segura das ciências humanas, isto é, a História, como não reconhecer que ela tem uma relação contínua com o fantasma?" Nesta altura, recorre a uma de suas referências fundamentais para afirmar: "É o que Michelet tinha compreendido: a História, em fim de contas, é a história do lugar fantasmático por excelência, isto é, o corpo humano; foi partindo desse fantasma, ligado nele à ressurreição lírica dos corpos passados, que Michelet pôde fazer da História uma imensa antropologia. A ciência pode, portanto, nascer do fantasma" (Barthes 1977: 44-5).

Barthes apontava no seu texto tanto para a consciência da historicidade de seu corpo, dramaticamente sugerida pela leitura do romance A Montanha Mágica, de Thomas Mann, como para a atitude que adotava no exercício do magistério: esquecer que o próprio corpo é histórico para lançar-se voluntariamente na ilusão de ser contemporâneo dos jovens corpos presentes de seus alunos, e não de seu próprio corpo, originário do passado. Esta atitude, tomava-a em consonância com a memória de Jules Michelet, que afirmara começar uma vita nuova aos cinqüenta e um anos, com nova

\footnotetext{
${ }^{1}$ Adotamos aqui a tradução de Leyla Perrone-Moisés para a Leçon inaugurale de Barthes, aceitando a própria justificativa da tradutora ao adotar aula, em lugar de lição (Barthes s/d: 73-4).

${ }^{2}$ Concordamos aqui com a tradutora de Barthes que prefere usar "fantasma", em lugar de fantasia. Leila Perrone-Moisés justifica que é "preferível usar fantasma e fantasmático, que indicam mais precisamente a origem inconsciente da imagem". idem: 82 .
} 
obra, novo amor. Na "aula inaugural", Barthes revelava que, embora mais idoso que o Michelet daqueles tempos, também entrava numa vita nuova. Das suas confissões, onde nada é gratuito, fica-nos a idéia de um renascimento a que o intelectual, especialmente aquele afeito ao ensino, deveria se entregar periodicamente.

Neste passo, devo indicar que começo por me apropriar das palavras de Roland Barthes e da sua identificação com Jules Michelet para falar de um fantasma que, idealizado no século XVIII e construído no século XIX, ocupa, há quase três décadas, uma parte fundamental das minhas preocupações de professor e pesquisador, desde os tempos de estudante nos cursos de graduação e pós-graduação. Este fantasma é a questão nacional na história, isto é, a nação como construção imaginária, tanto no plano da res gestas, como no plano da historia rerum gestarum. Esta inquietação reconhece a força simbólica de um fenômeno que, plasmado na experiência histórica do século XIX, continua a apresentar efeitos terrivelmente reais no século XX. Por outro lado, do ponto de vista epistemológico, esta construção imaginária, a nação, estabeleceu desde o século XIX alguns balizamentos para o conhecimento histórico, que podem nos levar a refletir sobre o aprisionamento dos historiadores, desde então, ao paradigma nacional. Há, portanto, duas dimensões básicas a serem consideradas: a nação como construção histórica imaginária e a nação como base de uma episteme para pensar a própria história.

Parto, desde o início, do ponto de vista de que a nação é uma construção histórica carregada de significações. Portanto, ao buscar sentido histórico no fenômeno nacional o que desejo compreender não é o mero reflexo de uma suposta realidade empírica dada, mas o próprio processo de elaboração simbólica. Isto porque assumo o pressuposto de Ernest Cassirer (1994: 317) de que "na história, a interpretação dos símbolos tem precedência sobre a coleta dos fatos", o que significa pensá-la no campo da hermenêutica, afastando-a da ciência natural. Diferentemente do físico, que pode repetir a experiência, a matéria prima do historiador, o passado, foi embora para sempre, o que impede, como observa Cassirer, a sua reconstrução num sentido físico e objetivo, como se fosse possível despertá-lo numa nova vida. Para Cassirer era muito nítido que o historiador, desde o início de sua investigação, não encontra 
"um mundo de objetos físicos, mas um universo simbólico - um mundo de símbolos" (idem: 285).

Apesar da questão nacional ter voltado, pelo menos desde os anos 80, a estar presente no centro dos debates nas ciências sociais ${ }^{3}$, para a maioria dos historiadores do século XX a nação se constituiu freqüentemente mais num dado do que num problema, quase como uma base natural da história a ser estudada. É como se os historiadores estivessem aprisionados, no que se refere ao fenômeno nação, a uma espécie de ilusão convincente, dotada de uma retórica de imagens que se impõem e coagem pela monotonia e pela monologia do discurso. Neste caso trata-se do discurso da nação que, desde sempre aparecendo como único, propõe-se com a naturalidade do que já existe, como real. Esta abordagem é inspirada na leitura que José Américo Motta Pessanha (1994: 33-55) faz - ao tratar do binômio radical sono e vigília e das tentativas de estabelecer distinções entre ficção e ciência, entre fantasia e verdade - do prisioneiro da caverna em Platão (República,VII). O prisioneiro, enquanto não realiza a conversão do olhar, só conhece o que lhe é apresentado pelo teatro da ilusão, produzido pelas sombras dos simulacros artefeitos que, iluminados pelo fogo artificial, são projetados no fundo da caverna. Enquanto não descobre a engenhosa montagem, o prisioneiro permanece preso ao ilusionismo que o fascina e subjuga pela repetição, pela homogeneidade da linguagem sem contradição ou alternativa.

Nesta direção, o nosso fantasma se constituiu numa ilusão convincente que aprisionou, desde o século XIX, a história e os historiadores. A compreensão deste fenômeno (que aprisiona a consciência) não pode ficar restrita à percepção do problema de um ponto de vista simplesmente funcional, como uma espécie de satisfação das necessidades de aglutinação das sociedades humanas ou, ainda, como resultado dos

\footnotetext{
${ }^{3}$ Para tanto, há exemplos significativos como as revistas francesas: Communications, ${ }^{\circ} 45$, de 1987, que apresentava o dossiê "Éléments pour une théorie de la nation" e Raison Présente, $\mathrm{n}^{\circ} 86$, do $2^{\circ}$ semestre de 1988, com o dossiê "La nation, réalités et fantasmes". Também são de 1985 as conferências de Eric Hobsbawm que deram lugar ao livro Nações e nacionalismo desde 1780: programa, mito e realidade (1990). Outra obra significativa havia surgido em 1983, o livro de Benedict Anderson: Imagined Communities. Reflections on the Origin and Spread of Nationalism (1989).
} 
acidentes de sua constituição histórica. Não há dúvida de que a nação preenche uma função identificatória coletiva que em outras épocas se localizava nos deuses da cidade ou na extensão espacial e temporal da pessoa do Rei. Cornelius Castoriadis (1986: 179) identifica que o papel exercido pela nação se dá por uma "referência triplicemente imaginária a uma 'história comum", e explica: “triplicemente, porque esta história é só passado, porque não é tão comum, porque enfim o que dela é sabido e serve de suporte a esta identificação coletivizante na consciência das pessoas é mítico em sua maior parte". Contudo, Castoriadis chama a atenção para o fato de que "esse imaginário da nação se revela mais sólido do que todas as realidades, como o mostram duas guerras mundiais e a sobrevivência dos nacionalismos".

Castoriadis, referindo-se aos autores "marxistas" da década de 60, época em que lança "Marxismo e teoria revolucionária", posteriormente publicado como a primeira parte de A Instituição Imaginária da Sociedade, afirmava que estes acreditavam eliminar todos os problemas provocados pela ideologia nacional dizendo simplesmente que: "o nacionalismo é uma mistificação", o que era, no entendimento de Castoriadis uma automistificação. Para ele não havia dúvidas do nacionalismo ser uma mistificação. O problema, porém, deveria ser localizado no fato desta mistificação ter efeitos tão maciça e terrivelmente verdadeiros, mostrando-se muito mais forte do que todas as forças "reais" que deveriam ter conduzido os proletários à confraternização, em lugar da adesão às guerras (idem: 179).

Benedict Anderson (1989: 12), ao tratar desta questão no marxismo já apontou para o fato do nacionalismo ter se revelado "uma incômoda anomalia para a teoria marxista", constituindo-se, por esta razão, num tema que "tem sido amplamente evitado, mais do que enfrentado". Anderson observa que o próprio Marx deixou brechas, indefinições e imprecisões a respeito do problema, mesmo no Manifesto Comunista, de 1848 , quando afirma que "O proletariado de cada país deve, naturalmente, antes de mais nada, ajustar contas com sua própria burguesia" (idem: 12). Benedict Anderson aponta, com razão, para esta contradição no pensamento marxista: por que a segmentação da burguesia, a sua identificação com o adjetivo nacional numa perspectiva teórica que procurou definir as classes sociais em termos 
das relações de produção? Nos desdobramentos do marxismo no século XX é possível encontrar autores que se quiseram marxistas vinculando categorias como modo-de-produção, classes sociais, forças produtivas a uma base territorial recortada pela dimensão nacional.

Com muita freqüência, historiadores revisionistas marxistas tentaram adaptar o conhecimento da história de uma dada nação às categorias marxistas. Sem refazer o objeto "história nacional" buscaram dar uma nova interpretação em universos temáticos já previamente demarcados pela construções liberais da história. O uso das categorias de procedência marxista não impediu, também nestes casos, o aprisionamento desses historiadores revisionistas ao paradigma nacional, muito pelo contrário chegou freqüentemente a favorecer o estranho casamento político entre o marxismo e o nacionalismo, em especial nos países do chamado Terceiro Mundo.

Benedict Anderson considera que "tanto a teoria marxista como a liberal têmse debilitado em um tardio esforço ptolomaico para "salvar o fenômeno" do nacionalismo; assim, o que se requer com urgência, seria "uma reorientação de perspectiva num espírito por assim dizer copernicano". Anderson chama a atenção, ainda, para a necessidade de conhecer como as nações "se tornaram entidades históricas, de que modo seus significados se alteraram no correr do tempo, e por que, hoje em dia, inspiram uma legitimidade emocional tão profunda" (idem: 12). Este autor toma as nações como "artefatos culturais", definindo-as como "comunidades políticas imaginadas" e apresentando a preocupação de que não sejam tomadas como "contrafação" e "falsidade". Anderson prefere assimilar o caráter de "invenção", existente no fenômeno, a "imaginação" e "criação". Neste sentido critica as formulações de Ernest Gellner, em Thought and Change (1964), alertando para o perigo de considerar a existência de comunidades "verdadeiras" que poderiam se sobrepor vantajosamente às nações. Para Anderson a distinção não deve ser feita pelo viés da falsidade/autenticidade, mas pelo estilo em que são imaginadas.

Porém Ernest Gellner, em outro livro, Nações e Nacionalismo (1983), publicado no mesmo ano do estudo de Anderson, não apresenta ênfase no caráter da falsidade, mas colabora para esclarecer a questão, tomando o nacionalismo como "um princípio 
político que defende que a unidade nacional e a unidade política devem corresponder uma à outra". Gellner, neste outro trabalho, aponta para o fato de que "é o nacionalismo que dá origem às nações, e não o contrário" (1983: 89). Parte, entretanto, do pressuposto de que o problema do nacionalismo não se coloca quando não existe Estado, apesar de ressalvar que isto não significa que o problema do nacionalismo surja em todo e qualquer Estado. Pelo contrário, observa Gellner, o fenômeno surge apenas em alguns Estados, o que leva a procurar saber quais os que são, realmente, confrontados com este problema.

Outra questão importante sugerida por Gellner é o papel do estabelecimento de culturas eruditas largamente difundidas, através de sistemas de comunicação estandardizados e baseados na instrução e na educação. Este processo seria responsável por muitas ilusões no trato da questão. Gellner observa que o nacionalismo "não é aquilo que parece e, sobretudo, não é aquilo que parece ser a si próprio"; para este autor as culturas que o nacionalismo diz "defender e revivificar são muitas vezes por ele inventadas ou alteradas de modo a ficarem irreconhecíveis" (idem: 87).

Gellner levanta, ainda, um problema fundamental na abordagem do fenômeno, a relação entre a cultura erudita e a construção do imaginário nacional. Para ele, o "nacionalismo constitui essencialmente a imposição de uma cultura erudita a uma sociedade" (idem: 90). As observações de Gellner são desmistificadoras do fenômeno, remetendo-o para o lugar da invenção, para o lugar por excelência da construção das representações da nação: a cultura erudita no âmbito do Estado. Eric Hobsbawm (1990), que há vários anos estuda o tema da nação na História Contemporânea, critica a preferência de Gellner em ver a questão "pelo alto", considerando que esta perspectiva torna difícil uma atenção adequada à visão dos de baixo na estrutura social. Contudo, Hobsbawm reconhece as dificuldades de trabalhar a questão no âmbito das pessoas comuns, que são o objeto da ação e da propaganda da nação, e aponta para a urgência de serem realizados estudos sobre a questão nacional nesta outra dimensão. Na verdade, o que Hobsbawm desejaria ver estudado são os lugares da recepção das construções imaginárias nacionais, os lugares sociais onde se dá a sua apropriação e assimilação. Ele tem clareza, todavia, 
de que os historiadores sociais contemporâneos, já aprenderam como investigar a história das idéias, das opiniões e dos sentimento no que chama de "plano subliterário". Com isto não precisam mais incorrer no erro de confundir os editoriais de jornais selecionados numa pesquisa com a própria opinião pública (Hobsbawm 1990: 20).

Hobsbawm dedicou um capítulo à questão nacional em cada uma das suas Eras (das Revoluções, do Capital, dos Impérios) dedicadas à História Contemporânea. A questão somente aparece diluída na Era dos Extremos. Porém, uma de suas contribuições fundamentais refere-se ao fato de que Hobsbawm foi revendo o problema ao longo de seus estudos, revendo mesmo o sentido das palavras "nação" e "nacionalismo" e revendo a cronologia dos fenômenos. Em Nações e Nacionalismo alerta para o fato das nações não serem "tão antigas quanto a história" ${ }^{4}$ e do sentido moderno da palavra não ser mais velho que o século XVIII. É possível perceber em Hobsbawm uma redefinição da cronologia do fenômeno: o primeiro tempo, no século XVIII, em especial a partir da conjuntura da Revolução Francesa, produzindo a idéia política de nação; o segundo tempo, o da construção do Estado-nação com a sua função de pedra angular do desenvolvimento econômico-capitalista e o terceiro tempo, o do nacionalismo - que emerge com a democratização da política. Este terceiro tempo corresponde ao momento em que, pela primeira vez, o sentimento nacional é transformado em força política, existindo e sendo mobilizado.

Hobsbawm, desde a primeira metade dos anos 80, vinha chamando a atenção para este terceiro tempo, que tornava possíveis os movimentos nacionais "de baixo", mais do que os "de cima". Assim considerava que é "neste momento que a nação começa a tornar-se um problema". Este é o momento do início do verdadeiro debate sobre a nação - designadamente no movimento socialista. Michel Löwy (1980: 85) já havia apontado para a relativa indefinição dos textos de Marx e Engels sobre a questão, indeterminação que prosseguirá na Segunda Internacional, antes da Primeira

\footnotetext{
${ }^{4}$ expressão usada por Walter Bagehot em Physics and Politics (apud Hobsbawm 1990: 13).
} 
Guerra Mundial e que culminará com Lenin tentando construir uma "doutrina revolucionária realista e coerente do direito de autodeterminação das nações" (Löwy 1980: 85). É importante ainda lembrar que Hobsbawm, em A Era dos Impérios 1875 1914 , já havia alertado para o fato da própria palavra "nacionalismo" ter aparecido pela primeira vez em fins do século XIX para descrever grupos de ideólogos de direita na França e na Itália, que brandiam entusiasticamente a bandeira nacional contra os estrangeiros, os liberais e os socialistas, defendendo a expansão agressiva de seus próprios Estados. Nacionalismo viria a substituir, portanto, a expressão "princípio de nacionalidade", que fizera parte do vocabulário político europeu desde 1830 (Hobsbawm 1988: 204). Um dos ícones da direita francesa, no século XX, Charles Maurras, definirá o nacionalismo como "a salvaguarda necessária à todos estes tesouros que podem ser ameaçados sem que um exército estrangeiro tenha atravessado a fronteira, sem que o território seja fisicamente invadido. Ele defende a nação contra o Estrangeiro do interior" (Maurras: 1937). Esta definição de Maurras exemplifica, para permanecermos no âmbito de um "pensamento francês", a face mais perigosa do fenômeno na construção do discurso da exclusão.

Demarcados os três tempos com o apoio de Hobsbawm, retornemos à palavra chave dessa discussão: a palavra nação. Nesta altura recorro ao historiador da gramática, Jacques Cellard, e ao livro que publicou, em 1989, intitulado Ah! Ça ira ça ira... Ces mots que nous devons à la Révolution, organizando um léxico das palavras que a tormenta revolucionária (1789-1799) criou para exprimir o que então se vivia, acreditava e sentia, numa língua ainda presa ao universo mental do Ancien Régime. Cellard, de início, observa que sob o Antigo Regime a palavra não implicava nenhuma forma particular de relações entre indivíduos, nem de organização jurídica dessas relações (Cellard 1989: 263). Recorre aos viajantes do século XVIII para exemplificar que estes falavam da "nation iroquaise" ou da "nation huronne" no sentido em que nós empregaríamos "tribo" ou "povo". Acrescenta Cellard: "É reino que, para a França, exprime a idéia de nação, assim como súdito exprime a de cidadão" (idem: 263). No Dicionário do brasileiro Antonio de Moraes e Silva, na edição de 1813, é possível encontrar nação sendo definida como: "A gente de um 
país, ou região, que tem Língua, Leis, e governo à parte", exemplificando com a "nação francesa, espanhola, portuguesa". Contudo Moraes registra "gente de Nação" para designar "os descendentes de judeus, cristãos-novos" e registra, ainda, nação como "raça, casta, espécie" (Moraes 1813, II: 332).

O aparecimento do sentido novo e revolucionário de nação data de 1789, quando Sieyès escreve: "O terceiro estado abrange portanto tudo isto que pertence à nação; e tudo isto que não é o terceiro estado não pode se olhar como sendo da nação" (apud Cellard 1989: 264). Esta nova nação surge como uma pessoa moral, uma entidade jurídica, dotada de consciência e de uma vontade autônoma. Num primeiro momento, na fase constitucional da Revolução, ela aparece associada ao rei através da lei, o que leva à divisa dos anos 1789 a 1792: "La Nation, la Loi, le Roi” (idem: 264).

Com a Revolução, portanto, mas especialmente após a execução do Rei, a palavra nação passa a ocupar um lugar central, tornando-se beneficiária “da transferência jurídica e emocional que faz passar da pessoa do rei para este ser coletivo novo os atributos da soberania”, como assinala Claude Nicolet (1982: 16). A nação se impõe doravante no centro do novo direito público, sem que seja necessário ou possível defini-la. Ela se torna um símbolo coletivo de identificação após a queda do Rei e assume sozinha todas as funções devolvidas à França pelos franceses. Pelo menos as funções internas, porque a nação está de qualquer forma fechada sobre ela mesma, ao passo que as funções exteriores, a defesa contra o inimigo estrangeiro em particular, ficam na alçada da pátria. Daí o uso extensivo de nacional para os valores políticos: a Assembléia, a vontade, a representação (parlamentar), a guarda, os bens são "nacionais" e não "patrióticos".

Jacques Cellard indica que o uso de nacionalizar surge em 1792, quer se tratassem de bens (nacionalizar as terras, os cavalos) ou de pessoas (nacionalizar os cidadãos é lhes inspirar o amor ao país); o verbo fará aparecer logo depois, 1794 ou 1795, a nacionalização. Aponta ainda para o surgimento, mais tardio, de nacionalismo, como a criação retrospectiva de um escritor anti-revolucionário, o abade Barruel (agostiniano, 1741-1820), que emprega o termo pela primeira vez nas suas Mémoires pour servir à l’histoire du jacobinisme (1798, III: 184). “O nacionalismo 
[escreve ele] tomou o lugar do amor geral. Então foi permitido [...] desprezar os estrangeiros, enganá-los e ofendê-los. Esta virtude foi chamada de "patriotismo" (apud Cellard 1989: 264). Contudo, se avançarmos no tempo para consultar o Dictionnaire Politique, editado por Pagnerre, em Paris, na década de 1840, com Introdução de Garnier-Pagès, não encontraremos o verbete nacionalismo, localizando apenas o registro de nação, nacional e nacionalidade. Este dicionário tinha como subtítulo Enciclopédia da Linguagem e da Ciência Política e era redigido por um conjunto de deputados, publicistas e jornalistas, o que indica a correção das observações de Hobsbawm ao considerar o nacionalismo como um fenômeno correspondente à democratização da política na segunda metade do século XIX europeu.

Os termos pátria e nação vinham sendo reelaborados, ao longo do século XVIII, nos textos dos pensadores. Na década de 1750 a controvérsia entre Voltaire e Rousseau já havia colaborado para definir os novos usos das palavras. À idéia de pátria são associadas as de liberdade, de felicidade, de virtude, trazidas das lembranças da Antigüidade (Leduc-Fayette 1974), da Inglaterra de Bolingbroke - The Idea of a Patriot King fora publicada em 1738 - ou das Repúblicas das Províncias Unidas. Enquanto Voltaire desconfiava da pátria, Rousseau lhe conferia um destino, defendendo a idéia da existência de um "caráter nacional" em cada país. Voltaire utiliza "nação", como Montesquieu, num sentido descritivo: "as nações do norte da Europa", "a Inglaterra, nação espiritual e audaciosa" (apud Furet-Ozouf 1989: 804), enquanto Rousseau defende que o "caráter nacional" precisa ser alimentado e respeitado. Rousseau propõe no seu Projet de Constitution pour la Corse, um verdadeiro juramento cívico para os cidadãos da ilha: “Eu me uno com o corpo, bens, vontade e com todo o meu poder à Nação corsa, para lhe pertencer em toda propriedade, eu e tudo o que de mim depende. Juro viver e morrer por ela" ${ }^{5}$.

Há um longo caminho a ser percorrido no amplo debate existente em torno da questão nacional na História. Por agora, fiquemos com a formulação contemporânea

\footnotetext{
${ }^{5}$ ROUSSEAU, J.J. Oeuvres Complètes (III: 913). Paris, Gallimard (Pléidade), tome III, p 913.
} 
de Gil Delannoi, que considera a nação como "um instrumento da consciência histórica e da consciência política" e o nacionalismo como "uma forma ideológica". Estes fenômenos constituem, na expressão desse autor, "uma caixa cheia de outras coisas: concepções de mundo, ideologias, etc". Porém funcionam, alerta Delannoi, uma vez que esta diversidade galvaniza, talvez porque seja, exatamente, "vazia, contraditória, difusa", o que faz com que todos possam nela se encontrar (Delannoi 1993: 1-17).

\section{II - No século da História}

Com os autores visitados na primeira parte deste texto, poderíamos conceber o nosso fantasma - a nação - como um fenômeno dotado de historicidade e cuja compreensão é central para a História Contemporânea, pelo menos desde os tempos da Revolução Francesa. Por outro lado, podemos considerá-lo como um artefato cultural profundamente vinculado à história do próprio conhecimento histórico desde o século XIX. Construído pela via do imaginário, este artefato precisou da história para se legitimar e para fazer crer que a identidade dos países estava assentada num passado frequentemente anterior à própria existência do Estado. Como observou Pierre Nora (1978: 424), o século XIX foi o tempo em que "a pesquisa da identidade de uma sociedade passava pelo sentimento nacional, portanto pela pesquisa de suas origens, pela história e pelo historiador".

Nesta altura é necessário afirmar que tomo a história da história como um campo específico de investigação - apesar de se constituir num território repleto de armadilhas, que pode levar o professor universitário a se transformar em alguém que fala sobre as construções históricas, realiza o inventário da produção de outros historiadores sem conseguir, no entanto, criar o seu próprio objeto. É neste sentido que muitas vezes desaconselhamos estudantes no início do ofício a iniciarem seus estudos pela via da historiografia. Isto porque considero que a investigação, no campo da história da produção do conhecimento histórico, deve ser precedida do exercício da elaboração de um objeto histórico específico, onde é preciso atravessar as dificuldades teóricas e metodológicas, mas também e principalmente as de ordem documental e arquivística. Todavia, estas ressalvas não significam a inexistência de um campo específico, muito pelo contrário, apontam para a complexidade da sua construção. 
A história das obras históricas e dos historiadores exige uma confrontação de métodos e tendências, bem como de sua evolução; implicando sempre em exame crítico. Este campo novo poderia ser designado como epistemologia da ciência histórica, para utilizarmos a expressão de Jean Walch (1989). Trata-se, sem dúvida, de um campo de investigação, de um tipo de pesquisa essencialmente reflexiva e abstrata, recorrente à filosofia, mais particularmente à teoria do conhecimento. Dessa modalidade de investigação resultará um aprofundamento da interpretação crítica dos caminhos da história e uma espécie de auto-avaliação no interior do próprio campo.

É preciso observar que toda interpretação dos fenômenos históricos, pela História, introduz uma transcendência da duração vivida num tempo construído, o tempo da história, para realizarmos o que Ernest Cassirer chamava de "reconstrução ideal". A epistemologia da ciência histórica, contudo, além do tempo histórico, compreende uma concepção ainda mais abstrata do tempo, vinculando-se, como observa Walch (1989: 8), na história da historiografia, a fatores psicológicos e lógicos, a categorias sociais como engajamento social e político, a fé, a racionalidade, etc. e a uma análise dos métodos históricos e dos paradigmas científicos. Portanto, se a subjetividade é inseparável da obra histórica, a epistemologia, desvendando suas origens e analisando seus esforços, pode obter uma classificação: das mentalidades, das doutrinas e das construções imaginárias dos historiadores, dos métodos da historiografia, de suas escolas e tendências e, finalmente, atingir uma sistemática, a ser construída, mas da qual poder-se-ão deduzir conclusões significativas quanto a natureza profunda do conhecimento histórico.

$\mathrm{Na}$ verdade, não podemos deixar de enfrentar os nossos fantasmas, identificando o teatro de ilusões das construções historiográficas, surpreendendo e expondo as ilusões convincentes, tentando realizar a conversão do olhar, tanto na pesquisa como na reflexão epistemológica, que deve realimentá-la permanentemente. Talvez porque nossa tarefa mais contemporânea seja, exatamente, discutir a natureza configurativa do conhecimento histórico, conscientes de sua história.

Vamos buscar aqui alguns momentos do discurso historiográfico do século XIX, especialmente da primeira metade, onde o recorte nacional na história assume rele- 
vância e passa a ocupar o primeiro plano da cena historiográfica. Nossa pequena viagem será à historiografia francesa e mais particularmente aos textos de um autor citado, desde o início de nossa exposição, por Roland Barthes: Jules Michelet. Este autor será invocado através de três temas motores na sua vasta e diversificada obra: a pátria, a nação e o povo.

No volume coletivo sobre a "nouvelle histoire", de 1978, dirigido por Le Goff, Chartier e Revel, Pierre Nora abre o verbete "Michelet" afirmando que: "Para todo historiador da escola nova, Michelet (1798-1874) faz figura de santo patrono, de herói epônimo" (Nora 1978: 424). Nora lembra duas lições inaugurais de historiadores no Collége de France, em que a menção à Michelet aparece na última frase das duas locuções. O primeiro era Fernand Braudel, evocando "la grande voix de Michelet" e o segundo Georges Duby, perseguindo o sonho de Michelet. Estas referências levam o autor a apontar para Michelet como patrono dos Annales - o que pode sugerir, pelo menos, um mal entendido. Neste aspecto, teríamos de um lado "o grande sopro épico, a projeção fantasmática a mais apaixonada e a mais literária, de outro o estudo científico com a utilização freqüiente de métodos quantitativos".

Porém, observa Nora, Michelet pode ser reivindicado, acertadamente, como um precursor da história nova. A imagem de Michelet no Panteon dessa história é uma imagem por vezes positiva e negativa, porém favorecida: pela abertura temática (o corpo, a natureza, a multidão, a psicologia coletiva); pela ambição de uma história “total"; pela inversão democrática dos interesses tradicionais em benefício de uma história das coletividades anônimas; pelo sentido das evoluções de longa duração; pelo sentido etnológico do passado; pelo gosto das transgressões históricas para uma integração da natureza; pela certeza de que a história vincula-se ao indizível; pelo seu sentido dos famosos "silêncios da história" e pela sua arte de fazer falar ao que vem da escuridão. Na verdade, Michelet é um escritor cuja presença na cultura francesa extrapola o campo historiográfico, tal a intensidade dramática do que produziu. Sua forma de escritura, porém, coloca em confronto a pesquisa contemporânea que, na observação de Nora (1978: 424), nos anos 70, ainda não havia encontrado a sua própria escritura, nem o seu papel e estatuto social. 
Jules Michelet atravessa a história escrita com uma dimensão poética que inquietou e fascinou críticos da linguagem, como Roland Barthes. Invocamos Michelet para fazer não exatamente a avaliação da sua obra, mas para buscar, em alguns de seus textos, a construção do recorte nacional na História do século XIX, com vistas a ilustrar o que chamamos de a construção de um paradigma nacional na historiografia do século XIX. Nosso recorte apenas indica que o campo de pesquisa-mesmo restrito ao caso de uma historiografia nacional - é infinitamente mais amplo do que a escolha que fizemos. Por que Michelet? Certamente pelo lugar que ocupa não apenas na história da história, mas na história da idéia de nação. Vejamos o que Lucien Febvre, num pequeno livro publicado em 1946, diria a respeito: "Sim, porque Michelet, francês no mais alto grau, francês portando nele não somente a França do presente, mas a França de vinte e cinco séculos - analista destes vinte e cinco séculos e não pois oportunista de uma conjuntura - sim, porque Michelet nunca fez outra coisa que traduzir, na sua língua magnífica e de todo seu coração, o sentimento da França eterna" (Febvre 1946: 82-3). Qual de nós poderia condenar o historiador rigoroso que, nesta passagem, se deixou trair ao tornar público "sentimentos nacionais" feridos pela guerra e pela ocupação estrangeira?

Febvre havia dedicado um curso, no Collége de France, ao historiador da nação francesa. Na quarta lição do curso "La formation du monde moderne, Michelet et le probléme de la Renaissance”, proferido em 1942-43, lança uma indagação, que ele mesmo responderá, sobre o poder de realização da obra de Michelet, atribuindo ao historiador o lugar de: "herdeiro e beneficiário de uma das maiores transformações produzidas, no curso de nossa história, na mentalidade do povo francês. Vamos chamá-la, no sentido largo da palavra, a revolução romântica, englobando sob esta etiqueta a boa parte dos préromantismos que a anunciaram" (Frebvre 1992: 46). Febvre, que considera Michelet como o maior lírico do século XIX francês, afirma: "foi ele que fez entrar os arquivos na vida; que, de papéis mortos, tirou sangue quente e vivo" (idem: 54).

Na Introdução à História Universal publicada em abril de 1831, Michelet escreveria que este pequeno livro também poderia ser intitulado Introdução à História 
da França, uma vez que havia chegado "pela lógica e pela história” à conclusão que "sua gloriosa pátria é doravante o piloto da nau da humanidade” (Michelet 1962: 35). Na Introdução, Michelet já apresentava sua concepção da história, considerando-a "como o triunfo progressivo da liberdade" e tomando-a como a narrativa de uma interminável luta "do homem contra a natureza, do espírito contra a matéria, da liberdade contra a fatalidade" (idem: 36). Nos quadros desta "História Universal" a Europa será percebida como "uma terra livre: o escravo que a toca é libertado; este foi o caso da humanidade, fugitiva da Ásia. Neste mundo severo do Ocidente, a natureza não dá nada dela mesma; ela impõe como lei necessária o exercício da liberdade" (idem: 40). A Europa vai sendo desenhada como o lugar da liberdade, como o lugar onde teria se realizado "o trabalho de libertação do gênero humano". Michelet interroga-se sobre a contribuição de cada uma "destas personagens políticas a que se chama de Estados, a França e a Itália, a Inglaterra e a Alemanha” (idem: 48).

A Europa moderna é tomada como "um organismo muito complexo" e a França localizada nas "questões de conjunto do mundo europeu” e em oposição aos outros Estados (idem: 49). Entre estes a Alemanha, mesmo antes da unificação, emerge como um outro a ser caracterizado em oposição à essencialidade da França; o mesmo procedimento é feito em relação à Itália, considerada como a "pobre Itália" que pouco mudou, sofrendo "a fatalidade de seu clima e do sistema estreito de sociedade" (idem: 60).

O tema do "cruzamento de raças", a mistura de civilizações opostas é percebido de maneira positiva, como "auxiliar o mais poderoso da liberdade" (idem: 61). Para Michelet "raças e idéias" se combinaram e se complicaram avançando para o Ocidente. "A mistura”, dirá ele, "imperfeita na Itália e na Alemanha, desigual na Espanha e na Inglaterra, na França é igual e perfeita" (idem: 61). Assim encaminha a apoteose européia da França considerando que:

"O que há de mais simples, de mais natural, de mais artificial, quer dizer de menos fatal, de mais humano e de mais livre no mundo, é a Europa; de mais européia, é minha pátria, é a França" (idem: 62). 
A França vai assumindo, desde então, a individualidade de uma pessoa. Assim é que Michelet identifica:

\begin{abstract}
"A Alemanha não tem centro, a Itália tampouco. A França tem um centro; una e idêntica há muitos séculos, ela deve ser considerada como uma pessoa que vive e se move. O signo e a garantia do organismo vivo, o poder da assimilação, se encontra aqui no mais alto grau: a França francesa soube atrair, observar, identificar as Franças inglesa, alemã, espanhola, das quais ela estava cercada. Ela as neutralizou uma a uma, e converteu todas à sua substância" (idem: 62).
\end{abstract}

Jules Michelet transforma a sua Introdução à História Universal numa verdadeira apologia da nação França, buscando-a no passado o mais remoto da Europa e inventando a sua especificidade. Tratava-se de um Michelet jovem, aos 33 anos, Maître de Conférences na faculdade de letras. Apesar da pouca idade já havia sido professor da Escola Nacional Superior (então chamada de Escola preparatória), professor da filha da Duquesa de Berry, e professor da princesa Clémentine, filha de Luiz-Felipe, tendo assumido, após a ascensão deste, o cargo de conservador-chefe da seção histórica dos Arquivos Nacionais. Porém, a Introdução à História Universal foi concebida numa espécie de explosão emocional e escrita, segundo o próprio Michelet, "nas calçadas em chamas de Paris", no clima do levante de julho de 1830, contra Carlos X, quando os trabalhadores e estudantes dominaram Paris por três dias. A história vivida nestes tempos havia ditado as primeiras palavras de Michelet nesta obra: "Com o mundo começou uma guerra que deve acabar com o mundo e não antes: aquela do homem contra a natureza, do espírito contra a matéria, da liberdade contra a fatalidade” (idem: 7). Surgia aí um Michelet pronto para o combate, revelando e projetizando o passado, "com uma abundância de linguagem feita de exaltação do presente", como observou Charles Morazé, em 1962: "No seu estilo se reconhece um eco dos discursos da Convenção, uma segurança de jovem general da Revolução, o ardor de um homem apenas feito [...], mas [...] alimentado da Enciclopédia e de Rousseau: em suma, um campeão da França de 1830” (Morazé 1962: 7). 
Na construção grandiosa do passado francês, percebido no conjunto do passado europeu, Michelet ainda diria:

"Sabe-se que a França se fez italiana no século XVI, inglesa no fim do XVII. Em revanche, no século XVIII e no nosso, ela afrancesa as outras nações. Ação, reação; absorção, reabsorção, eis o movimento alternativo de um verdadeiro organismo" (Michelet 1962: 64).

Michelet perguntava, ainda, qual era a natureza da ação da França e a explicava através do "amor das conquistas" como o pretexto das guerras francesas, o que era enganoso. De qualquer forma reconhecia "o proselitismo" como "o mais ardente móvel”, afirmando:

"O Francês quer sobretudo imprimir sua personalidade aos vencidos, não como sua, mas como tipo do bom e do belo; é sua crença ingênua. Ele acredita que não pode fazer nada de mais proveitoso no mundo que lhe dar suas idéias, seus costumes e suas modas".

Michelet distinguia a atitude francesa da postura da Inglaterra e de Roma, dotadas de um comportamento político egoísta e material. A atitude francesa, contrariamente, era de assimilação das inteligências e conquista das vontades; o que ela deixava atrás de seus exércitos era uma parte de si. Neste ponto, indica Michelet:

"Nossa língua reina na Europa; nossa literatura invadiu a Inglaterra sob Carlos II, a Itália e a Alemanha no último século; hoje, são nossas leis, nossa liberdade tão forte e pura,... Assim vai a França no seu ardente proselitismo, em seu instinto simpático de fecundação intelectual.” (idem: 64).

A França moderna cumpria, para Michelet, o papel que Roma ocupara na Antigüidade, fazendo com que os franceses se constituíssem no "povo legislador dos tempos modernos". A Revolução Francesa permitira, no seu entendimento, o casamento da legislação germânica e romana no seu Código Civil. Ela era também a nação que possuía a capacidade de dar conta da História como ação e narração, diferentemente da Alemanha, que seria mais afeita à epopéia do que à história, porque 
desdenharia o presente. Somente a França possuía a acuidade de lidar com o presente - que ela apreende com "uma singular vivacidade".

Ao lado desta capacidade de lidar com a história e com o presente a França seria o "país da prosa”. Perguntará Michelet: “O que são todos os prosadores do mundo ao lado de Bossuet, de Pascal, de Montesquieu e de Voltaire?” (idem: 65). Para ele a prosa era a última forma de pensamento, a mais distante do sonho e a mais próxima da ação. Portanto, da passagem do simbolismo mudo à poesia, da poesia à prosa, haveria um progresso para a "igualdade das luzes", uma espécie de "nivelamento intelectual”. Desta forma, da hierarquia misteriosa das castas orientais, teria saído a aristocracia heróica; desta, a democracia moderna. O "gênio democrático" da França surgiria exatamente no seu caráter eminentemente prosaico: por aí a nação francesa estaria destinada a conduzir todo "o mundo das inteligências à igualdade”. Este "gênio democrático" deveria ser buscado no passado medieval, no papel antifeudal dos monarcas e mesmo no sacerdócio anti-aristocrático dos Druidas. Chega a afirmar: "O tipo do rei de França é um santo".

O padre e o rei favoreciam igualmente, recorda Michelet, a libertação dos servos:

"todo homem que escapa à servidão local da terra lhes pertencem, pertencem ao poder central, abstrato, espiritual. A eles caberia a libertação de cidades inteiras, a criação de comunas e a organização de um exército anti-feudal".

Michelet completa afirmando que o povo, "que só chegava à liberdade na pessoa do padre, aparece pela primeira vez sob sua forma própria” (idem: 66). Logo o padre e o monarca viriam a se arrepender de terem suscitado a turbulenta liberdade das comunas - que se voltava contra eles.

Michelet reconhece, no entanto, que se a liberdade das cidades tivesse prevalecido e se as comunas tivessem subsistido, a França, coberta de repúblicas, não teria jamais se tornado uma nação, como era o caso da Itália, uma vez que as cidades teriam absorvido os campos. Michelet compara as conquistas da França com a extinção do feudalismo, marcando as diferenças com a Alemanha, a Itália e a Inglaterra. Esta última, objeto das críticas mais violentas, será percebida como o lugar do orgu- 
lho. Olhando para a história da Inglaterra, após enumerar os equívocos da sua trajetória, Michelet afirma: "o heroísmo não é ainda a liberdade. O povo heróico da Europa é a Inglaterra, o povo livre é a França” (idem: 69). A França é, portanto, o lugar da liberdade na igualdade, mas é importante registrar que se trata da igualdade dos direitos, da igualdade dos meios de chegar às luzes e ao exercício dos direitos políticos. No recorte da construção de uma identidade para a França, Michelet retoma a Alemanha, como antítese, ao afirmar:

“A França não é uma raça como a Alemanha; é uma nação. Sua origem é a mistura, a ação é sua vida. Toda ocupada do presente, do real, seu caráter é vulgar, prosaico. O indivíduo retira sua glória de sua participação voluntária no conjunto; ele também pode dizer: Je m'appelle légion”.(idem: 71).

Michelet destaca que nenhum outro povo, resultante da mistura e da ação, teria guardado sua pureza como a França. Nada ali é perdido, uma vez que os franceses sempre retornam “pelo bom senso, à idéia de ordem”. Por outro lado, a virtude francesa não seria "a inocência, a ignorância do mal, esta graça da infância, esta virtude sem moralidade", a virtude francesa para Michelet é "a experiência, é a ciência, mãe séria da liberdade”. A idéia de ordem sairia, na experiência francesa, da sensibilidade incerta e móvel para entrar no domínio imutável da razão. Assim, Michelet vai buscar na experiência da Revolução de Julho, apontando para a sua singularidade, o "primeiro modelo de uma revolução sem herói, sem nomes próprios". Dirá Michelet: "La societé a tout fait” (idem: 72). A sociedade fez tudo. Após a vitória, os heróis teriam sido procurados e o encontrado foi "todo um povo".

A História do pensamento encontra, no entender de Michelet, na França, o lugar da "nova revelação" e da sua explicação. A França seria a responsável pela interpretação, tradução e popularização das soluções sociais ou intelectuais:

"A reforma do saxão Lutero foi democratizada pelo gênio Calvino. A reação católica do século de Luís XIV foi proclamada diante do mundo pelo dogmatismo soberbo de Bossuet. O sensualismo de Locke só se tornou europeu passando por Voltaire, por Montesquieu - que teria sujeitado o desenvolvimento da sociedade à influência 
dos climas. A liberdade moral reclama, em nome do sentimento, por Rousseau, em nome da idéia, por Kant; mas só a influência do francês foi européia" (idem: 75).

Michelet conclui que "cada pensamento solitário das nações é revelado pela França”. Para o autor: "Ela diz o Verbo da Europa, como a Grécia disse o da Ásia" (idem: 76). A França se encarregaria, na época moderna, portanto, de divulgar, na teoria e na prática, o "sentimento da generalidade social", de ampliar o "pontificado da nova civilização". Esta, no que ela tem de mais jovem e fecundo no mundo, não estaria na América, "filha séria que imitará por longo tempo", mas na "velha França, renovada pelo espírito". Ao fundar a França como o lugar da civilização Michelet estabelece também o lugar dos outros a serem tocados, no futuro, pela novidade: a Inglaterra e a Rússia, aprisionadas pelo mundo bárbaro; a Espanha, ainda presa à "profunda demagogia monacal que a governa", permanece fechada à democracia moderada da França - saindo do domínio dos monges, poderia fazer com que a "civilização ocidental atingisse a África"; a Itália estaria mais próxima da França, preparada pelo gênio anti-feudal da Igreja. A França, portanto, aparece como "chefe desta grande família", síntese de uma história comum, onde Carlos Magno e Bonaparte se encontram na "pátria" condutora dos povos na "estrada misteriosa do futuro" (idem: 77).

De todas as obras produzidas pela geração de historiadores franceses da Restauração e da Monarquia de Julho, a mais importante e a de maior prestígio intelectual foi, sem dúvida, a Histoire de France, de Jules Michelet. A esta obra foi dedicada quase toda uma vida, o que explica a sua amplitude. No conjunto, na edição Flammarion, ela ocupou vinte e seis volumes. Há uma verdadeira unanimidade em torno das suas qualidades estilísticas e do valor literário de uma obra cuja escritura foi marcada pela paixão. Também parece ser consensual o fato de nenhuma obra histórica, no seu tempo, ter atingido a mesma vivacidade na narração dos eventos e das personagens. Porém há outro aspecto a ser ressaltado: o lugar que as fontes documentais originais ocuparam na sua elaboração historiográfica. E isto se dá, nesta primeira metade do século XIX, exatamente na época em que, pela primeira vez, 
os grandes arquivos franceses se tornaram acessíveis para o público. Neste sentido, sua obra procurou deliberadamente se constituir num quadro bastante completo da história de uma nacionalidade; percorrendo-a desde a conquista romana até o início do século XIX. Ao escrevê-la, Michelet estava interferindo na própria construção imaginária do país, buscando o seu passado num tempo o mais recuado possível e nele assentando alguns dos marcos identificatórios fundamentais da comunidade imaginária dos franceses.

A Histoire de France pode ser lida, na sugestão de Guy Bourdé e Hervé Martin (1983: 115-136), em dois níveis e com apreciações opostas. Num nível de leitura, pelos seus traços, tratar-se-ia "de um monumento de ideologia pequeno-burguesa". Um simples reagrupamento lexical, em torno da palavra França, faria saltar de imediato: "luzes", "alma", "pessoa", "filha de sua liberdade", "fez a França", etc. Porém, a obra é também a expressão de uma relação vital entre o autor e seu trabalho. Em torno do termo central "livro" se reagrupam: "vida", "lentidão", "método", "forma", "cor", "harmônico", "único evento", "me Crou”, etc. A sua leitura da nação é apaixonada e atravessada por essa dimensão pessoal, individualizada, onde a sua biografia se confunde com a da França, que ele toma como pessoa. É isto que faz com que Barthes o descreva como um devorador de história, animado por uma verdadeira fúria de trabalho, curvando-se a uma disciplina monacal para tentar satisfazer este apetite insaciável.

Em 22 de fevereiro de 1869, Michelet passa a redigir seu grande prefácio à Histoire de France, cujo décimo-sétimo e último volume havia sido posto a venda em 10 de outubro de 1867, e que Lacroix queria reeditar. Há muito que Michelet se interrogava sobre seu método e sua vocação, o que o levou a dispor de vários textos que poderiam ser refundidos. Ele opta em "repartir [suas] recordações por três obras: o Préface à l'Histoire de France, L'Enfant, Le livre des livres"; as duas últimas permanecem como projetos. A redação do novo prefácio torna-se, então, mais cômoda e o manuscrito completo pode ser remetido para Lacroix, em 12 de setembro de 1869.

Uma versão inédita do prefácio à Histoire de France, remontado em 1869, foi encontrada, ainda na forma manuscrita, por Paul Viallaneix, nos papéis de Michelet existentes na Biblioteca Histórica da Cidade de Paris. Neste texto, assim como no 
Prefácio publicado, o autor define com nitidez suas opções numa espécie de autoavaliação, como quando anota:

"Meu progresso foi enorme do segundo para o terceiro volume. Eu havia sido sobretudo escritor e artista. Eu fui verdadeiramente historiador.

Eu reingressava na História com uma grande alma toda nova, um sentido a mais: o sentido do povo, o sentido, a inteligência, o amor das massas obscuras, que eram contudo nossa França, nossa família, nosso sangue, e nós mesmos. A sensibilidade, móvel e freqüentemente por demais dispersa nos dois primeiros volumes, se concentra, se fixa, dá à narrativa um acento grave e forte, cada vez mais profundo." (apud Viallaneix s/d: 10).

A época de Michelet foi propícia para a sua ambição de escrever, pela primeira vez, uma vasta História da França fundada em textos originais. Não era possível, ainda, realizar uma história geral fundada sobre os princípios dos Saint-Simonianos, uma vez que isto exigiria estudos prévios, longos e difíceis, sobre a história das técnicas, da economia, da base social, que só seriam realizados plenamente no século XX. Esta história, mais científica e construída sobre dados "mais objetivos" ainda não estava ao alcance da geração dos românticos. Michelet, ao longo de três décadas, comporia uma história dos acontecimentos e dos personagens históricos. Contudo não deixou de perceber o que hoje chamamos de fontes não convencionais, como a arquitetura, a escultura e a pintura, principalmente no trato da Idade Média (Haskell 1995), usando-as de maneira acessória.

Michelet ocupou a chefia da seção histórica dos Archives Royales, cargo que exerceu durante seis anos, tendo acesso privilegiado às fontes mais importantes, paralelamente à Bibliothèque Royale, para compor a História da França. No Prefácio de 1869, ele registra:

"Nenhum historiador, que eu saiba, fez uso de peças inéditas, antes do meu ter-
ceiro volume (coisa fácil de verificar). Isso começou pelo emprego que fiz, na
minha história, do misterioso registro do Interrogatoire du Temple, fechado por
400 anos, oculto, emparedado, proibido sob as penas mais graves, ao Tesouro
da Catedral, que os Harlay levaram, que veio à Saint-Germain-des-Prés, depois 
à Biblioteca. A crônica, então inédita, de Dugueslin também me ajudou. O enorme depósito dos Arquivos me forneceu um grande número de atos de apoio destes manuscritos, e ainda sobre outros assuntos. É a primeira vez que a história tem uma base tão séria (1837)".

Gabriel Monod, em 1923, sintetizou as observações de Michelet a respeito da documentação trabalhada: "Ele diz que a história, sendo obra de arte ao mesmo tempo que de ciência, ele a desembaraçou dos andaimes que prepararam a construção, mas que ela está principalmente fundada sobre as grandes coleções de atos, impressos e manuscritos, Ordem Régias, Trésor des Chartes, Registres du Parlement, Actes des Conciles, Recueil des actes de l'histoire d'Angleterre, Status du Royaume d'Angleterre, que fornecem autênticos Anais e permitem datar, confirmar e contradizer as narrativas dos cronistas. Ele acrescente que foi necessário muito tempo para interpretar estes documentos, controlar as crônicas pelos atos, os atos pelos cronistas".

Roland Barthes, no texto "Aujord'hui, Michelet", publicado no número especial de L'Arc dedicado ao historiador francês, comenta que nas suas primeiras leituras do autor o que surpreendia era "a insistência temática desta obra", mas que vinte anos depois, ao lado da evidência temática ele encontrava outro elemento surpreendente: "uma certa perturbação da discursividade". Para Barthes a cena micheletiana é repleta de esconderijos, sem deixar de ser inteligível no plano de cada frase, uma vez que nada é mais claro do que o seu estilo; contudo, esta cena torna-se "enigmática no plano do discurso".

Barthes considera que o que nos separa de Michelet é evidente e principalmente a passagem do marxismo. Não se trata somente do advento de um novo tipo de análise política, mas também de todo um conjunto implacável de desmistificações conceituais e verbais. Barthes identifica um pathos, do seu discurso, como obstáculo. Este pathos, generoso, moralizante, lírico, humanista, seria tomado, hoje, com uma ponta de depreciação, como alimentado pela ideologia pequeno burguesa e liberal da década de 1840. Barthes identifica, em Michelet, um discurso descontínuo, encontrando aí exatamente a sua beleza. A ultrapassagem das barreiras, na leitura de 
Michelet, daria acesso a "uma obra absolutamente suntuosa, livre, moderna, emancipada e, ainda em grande parte [reitera Barthes] enigmática".

O livro O Povo, de 1846, é uma espécie de profissão de fé, de catecismo da nacionalidade, dotado de uma profunda dimensão religiosa, apesar do anticlericalismo voltaireano de Michelet. Viallaneix já havia alertado para esta dimensão religiosa na sua obra, quando afirmou que era preciso "levar a sério o vocabulário religioso presente na Introduction à l'Histoire de la Révolution, uma vez que "revolução" e "revelação" aparecem nesse texto como sinônimos. No caso do discurso de O Povo, porém, parece não haver dúvidas quanto a este aspecto. O espírito catequético aparece nitidamente numa de suas últimas páginas:

"Consolado, acariciado, feliz, livre de espírito, que a criança receba nos bancos escolares o alimento da verdade. Que antes de mais nada saiba que Deus lhe fez a graça de conceder-lhe essa pátria, pátria que promulgou, que escreveu com o próprio sangue, a lei da eqüidade divina, da fraternidade; saiba a criança que o Deus das nações falou pela boca da França.

Antes de mais nada a pátria como dogma e princípio. Depois, a pátria como lenda: nossas duas redenções, pela santa Donzela de Orléans, pela Revolução, o ímpeto de 92, o milagre da jovem bandeira, nossos jovens generais admirados, pranteados pelo inimigo, a pureza de Marceau, a magnanimidade de Hoche, a glória de Arcole e Austerlitz, César e o segundo César, em quem nossos grandes reis ressurgiam ainda maiores. Mais alta ainda a glória de nossas assembléias soberanas, o gênio pacífico e verdadeiramente humano de 89, quando a França ofereceu a todos, tão cordialmente, a liberdade e a paz... Enfim, acima de tudo, como lição suprema, a imensa capacidade de devotamento, de sacrifício, que nossos pais demonstraram, e como tantas vezes a França deu a vida pelo mundo" (Michelet 1988: 227-8).

Alguma dificuldade resulta, em Michelet, como em outros autores românticos do seu tempo, da tentativa de construir uma santificação simultânea de dois seres coletivos diferentes: povo-entidade propriamente humanitária e ecumênica e França-entidade nacional particular. A solução teórica encontrada para esta dificuldade é tornar o país França campeão do "Povo universal", seu herói sofredor e salvador. E esta dimensão já 
havia aparecido na Introdução à História Universal, de 1831, quando Michelet afirmara: "que a França explicará o Verbo do mundo social que nós desejamos começar".

Michelet tentará construir uma teoria geral da Nação, aplicável a cada povo e que representaria a comunidade universal como uma coleção de almas nacionais, de sorte que toda nação representasse, de certo modo, uma realidade espiritual análoga àquela da França. No entender de Michelet "a pátria” seria, para todos os homens, a "iniciação necessária à pátria universal”. Porém, na tentativa de ampliar a percepção da humanidade, Michelet não consegue deixar de marcar que a "pátria francesa" é o guia de todas as outras, como quando afirma:

"Todo grande povo representa uma idéia importante do gênero humano. Mas isto, grande Deus, é mais verdade no caso da França".

É possível detectar contradições entre o humanitarismo e o nacionalismo de Michelet e seus contemporâneos. Há, todavia, nesta questão uma acentuada dimensão religiosa na construção do particularismo nacional, onde o princípio de supremacia do coletivo é marcado profundamente por um fervor sacralizante da construção da entidade nacional identificatória.

A História da Revolução Francesa, de Jules Michelet, começou a ser escrita em 1846 e impressa, por partes, a partir de 1847, constituindo até os nossos dias uma das peças histórico-literárias mais importantes sobre a Revolução de 1789 . No prefácio de 1847, Michelet ecreveu na abertura:

"A cada ano, quando desço de minha cátedra, quando vejo a multidão escoar, mais uma geração que não voltarei a ver, meu pensamento retorna a mim.

O verão avança, a Cidade está menos povoada, a rua, menos ruidosa, e a calçada, mais sonora ao redor do meu Panteão. Suas grandes pedras brancas e negras ressoam sobre os meus pés.

Volto a mim. Interrogo meu ensinamento, minha história, seu todo poderoso intérprete, o espírito da Revolução" (Michelet 1952: 1).

A Revolução, para Michelet, era detentora de todos os segredos dos tempos anteriores. No "espírito da Revolução" estaria contida a consciência que a França 
teve de si mesma. O "ator principal" da Revolução - esta entidade que libertava e dava consciência à Nação era "o povo". Lucien Febvre, tomando esta questão, acentuará, tendo em vista a construção micheletiana, que, entre os feitos da Revolução, o que foi capital é que "ela promoveu o povo à dignidade de agente e por consequiência de sujeito mesmo da História" (Febvre 1992: 75). Antes, observa Febvre, "a história fora feita para o rei, o príncipe, o general, o ministro", ... "somente eles a faziam, somente eles a ditavam". "E o historiador quando não estava lá para servir diretamente à uma operação precisa, só tinha um dever, celebrar, e uma palavra de ordem, agradar" (idem: 75). Diante desta constatação, na 6 licão, acrescentará Lucien Febvre: "A história dos povos, a história das civilizações, aquela que vale a pena ser estudada, que conta como fator do espírito humano - esta história nasceu na hora em que nasceu a Grande Revolução" (idem: 75). E isto foi obra da historiografia do século XIX.

Gabriel Monod, em 1876, no primeiro número da Revue Historique, que acabara de criar, constatava com orgulho: "Nosso século é o século da história". Ele retomava, afirmativamente, a profecia que, no início dos anos 1820, Augustin Thierry havia lançado: "a história seria o emblema do século como a filosofia o fora no século XVIII". Ao longo do século XIX a história tornou-se um saber institucionalizado na Universidade, uma disciplina para ser ensinada ao conjunto dos cidadãos, uma disciplina que tinha como tarefa realizar a genealogia da nação. Neste século da história os historiadores tiveram a tarefa de escrever a biografia da nação. Ao fazêlo contribuíram para construir, do ponto de vista imaginário, a própria nação.

No caso francês, os contemporâneos de Jules Michelet, os grandes historiadores, foram muitas vezes estadistas, naquela França que a historiografia queria criar e legitimar no passado. Thierry, Mignet, Guizot, Thiers, Quinet viveram, no calor da hora, a construção da história na realização de um projeto nacional e civilizatório, em que a história esteve a serviço do patriotismo. Esta foi a tarefa de toda uma geração que tomou a história como "árvore genealógica das nações européias", para usar uma expressão de François Furet (1979: 40). No século XIX, os historiadores se mudaram para sua casa própria, a universidade, como observou Peter Gay (1990: 27). A partir 
daí exerceram, na pesquisa e no ensino da história, a pedagogia nacional, definindo um campo de conhecimento e um campo de compromissos conscientes e inconscientes.

No Novo Mundo, a inspiração micheletiana e de seus companheiros também atingia o mundo letrado dos inventores tropicais de nacionalidades, como, por exemplo, o nosso Pereira da Silva, membro do Instituto Histórico e Geográfico Brasileiro, da Academia de Ciências de Lisboa, do Instituto Histórico e Geográfico da França e das Sociedades de Geografia e dos Economistas de Paris. Em 1864, ao introduzir a sua História da Fundação do Império do Brasil, a maneira de Michelet, pelo menos nas intenções, também esboçará a procura de um povo, afirmando:

"Tive sempre gosto pela história. Não a quero, porém, para saber datas, estudar vidas de príncipes e personagens ilustres, e aprender o número das guerras e combates que se pelejaram. Prefiro a que examina a fundo a sociedade inteira, que desce da cúpula elevada até o humilde chão do povo miúdo, descriminando as escalas e camadas pelas quais se derrama a nação, e o sentir, o sofrer, o gozar e o aspirar de cada um dos súditos. Agrada-me mais a que desenha os traços da administração pública, no mais largo sentido desta palavra, social, política, civil e econômica. Assim compreende a história o povo e a nação toda, e a apresenta de perfil, de face, no corpo, na alma e no espírito. Afigura-se-me então a história como o mais moralisado, instrutivo, agradável e sublime dos ramos literários" (Pereira da Silva 1864: 7).

Tenho a nítida consciência de que faltaram muitas vozes na emancipação do nosso fantasma. Esta, entretanto, é apenas uma parte, não conclusiva, de uma longa conversa que pretendo não ver interrompida. Os nossos historiadores do passado não tiveram a universidade, como casa própria, no século XIX brasileiro, porque ela chegou tardia entre nós. Suas elaborações nasceram, na maioria das vezes, fora do âmbito acadêmico, como ensaios de interpretação de uma nação que, muitas vezes tentaram inventar. Seus textos clamam pelo nosso estudo, são representações do passado, nós o sabemos, mas são essas representações: lidas, relidas e criticadas que, associadas às novas invenções, podem nos conduzir para "a nossa alteridade autêntica, os outros possíveis do homem em sua singularidade absoluta", como diria Cornelius Castoriadis. Resta-nos, ainda, um fantasma para evocar. Jules Michelet, como lembra Barthes, repetiu inúmeras vezes e em todos os seus prefácios que ele 
nascera povo, que o povo era seu pai. Contudo ele encontrou, sempre, um obstáculo para esta incorporação mágica. Incorporação que ele desejou ao longo de toda a sua vida: encontrar o povo, viver o povo, se alimentar com o povo, se aquecer com o povo. Porém onde estava este obstáculo? Estava no que Barthes identifica como a sua "parole". E Michelet diria, decepcionado: “Je suis né peuple, jávais le peuple dans le coeur... Mais sa langue, sa langue, elle m'était inaccessible. Je n'ai pu le faire parler..." O impasse de Michelet, Barthes o encontrou numa questão de linguagem: "falar como o povo". Aí ele resume toda sua obra, concluindo assim o pequeno livro, de 1954, dedicado a Michelet "foi possivelmente o primeiro dos autores da modernidade a não poder cantar senão uma impossível parole".

\section{Referências Bibliográficas}

ANDERSON, Benedict. Nação e Consciência Nacional. São Paulo, Ática, 1989.

BARTHES, Roland. Aula. São Paulo, Editora Cultrix, s.d. . Michelet. Paris, Seuil, 1988 (1ª ed. 1954, na coll. "Écrivains de toujours"). BOURDÉ, G. e MARTIN, Hervé. Les Écoles Historiques. Paris, Éditions du Seuil, 1983.

CASSIRER, Ernest. Ensaio sobre o Homem: introdução a uma filosofia da cultura humana. São Paulo, Martins Fontes, 1994.

CASTORIADIS, Cornelius. A Instituição Imaginária da Sociedade. $2^{\mathrm{a}}$ ed. Rio de Janeiro, Paz e Terra, 1986, p.179.

CELLARD, Jacques. Ah! Ça ira ça ira... Ces mots que nous devons à la Révolution. Paris, Balland, 1989.

DELANNOI, Gil. "La Teoria del nacionalismo y su ambivalencia" in Teorías del Nacionalismo (org. por Gil DELANNOI e Pierre-André TAGUIEFF). BarcelonaBuenos Aire-México, Editorial Paidós, 1993.

DICTIONNAIRE POLITIQUE. Encycclopédie du Langage et de la Science Politiques, redigé par une réunion de députés, de publicistes et de journalistes, avec une Introduction par Garnier-Pagès. $3^{\text {eme }}$ édition. Paris, Panerre Éditeur, 1848.

FEBVRE, Lucien. "Parler de Michelet" in Michelet. Genève-Paris, Traits, 1946. Michelet et la Renaissance. Paris, Flammarion, 1992.

FURET, François. “La Nacissance de l'Histoire” in Histoire no 1, mars, 1979. 
FURET, François e OZOUF, Mona. Dicionário Crítico da Revolução Francesa. Rio de Janeiro, Nova Fronteira, 1989.

GAY, Peter. O Estilo na História. São Paulo, Companhia das Letras, 1990.

GELLNER, Ernest. Nações e Nacionalismo. Lisboa, Gradiva, 1993.

GELLNER, Ernest. Thought and Change. Londres, Weidenfeld e Nicholson, 1964.

HASKELL, Francis History and its Images. Art and the interpretation of the Past. Yale University Press (New Haven), 1995.

HOBSBAWM, Eric J. A Era dos Impérios (1875-1914), Rio de Janeiro, Paz e Terra, 1988. Nações e nacionalismo desde 1780: programa, mito e realidade. Rio de Janeiro, Paz e Terra, 1990

LEDUC-FAYETTE. J.J. Rousseau et le Mythe de l'Antiguité. Paris, Vrin, 1974.

LÖWY, Michel. "El problema de la historia: observaciones de teoría y método" In LÖWY, M. e HAUPT, G. Los Marxistas y la Cuestion Nacional. Barcelona, Fontanamara, 1980.

MAURRAS, Charles. De la Politique Naturelle au Nationalisme Intégral (textes choisis). Paris, VRIN, 1972.

MICHELET, Jules. Introduction à L'Histoire Universelle. Paris, Armand Colin, 1962. "Préface de 1847" in Histoire de la Révolution. Paris, Gallimard, 1952. O Povo. São Paulo, Martins Fontes, 1988.

MORAES SILVA, Antonio. Diccionario da Língua Portugueza. Lisboa, 1813.

MORAZÉ, Charles. "Préface" à MICHELET, Jules. Introduction à L'Histoire Universelle. Tableau de la France. Préface à L'Histoire de France. Paris, Librairie Armand Colin, 1962.

NICOLET, Claude. L'Idée Républicaine en France (1789-1924). Essai d'Histoire Critique. Paris, Gallimard, 1982.

NORA, Pierre. Verbete "Michelet" In La Nouvelle Histoire (dir. por Le Goff, J; Chartier, R.; REVEL, J.) Paris, C.E.P.L., 1978.

PEREIRA DA SILVA, J. M. História da Fundação do Império Brazileiro. Rio de Janeiro, Garnier, 1864.

ROUSSEAU, J.J. Oeuvres Complètes (III: 913). Paris, Gallimard (Pléidade), tome III.

VIALLANEIX, Paul “Jules Michelet. L'Héroisme de l'Esprit”, in L'Arc, n. 52, s/d.

WALCH, Jean. Les Maîtres de l'Histoire (1815-1850). Genève-Paris, Éditions Slatkine, 1989. Historiographie Structurale. Paris, Masson, 1990. 